\title{
Zaburzenia odżywiania się - częsty problem współczesnej młodzieży
}

\author{
Eating disorders - a common problem of modern youth
}

DOROTA KOCHMAN ${ }^{1}$, MARZENA JASZCZAK ${ }^{2}$

1 Państwowa Uczelnia Zawodowa we Włocławku, Instytut Nauk o Zdrowiu

2 NZOZ „Alfa-Med” Bodzanów, Powiat Płocki

\section{Streszczenie}

Wstęp. Zaburzenia odżywiania się stanowią bardzo ważny problem zdrowotny XXI wieku zarówno w Polsce jak i na świecie. Dotyczy on przede wszystkim dziewcząt w wieku dojrzewania oraz młodych kobiet, jednakże coraz częściej także chłopcy cierpią na zaburzenia odżywiania. Grupa ta, pod względem tworzenia własnych postaw żywieniowych, charakteryzuje się wysoką podatnością za wpływ społeczno-kulturowy i rodzinny.

Cel. Celem pracy jest analiza wybranych zaburzeń odżywiania w światle literatury przedmiotu.

Materiał i metody. W pracy dokonano przeglądu literatury poświęconej zaburzeniom odżywiania.

Przegląd. Zaburzenia odżywiania definiowane są jako szkodliwy dla jednostki sposób odżywiania przejawiający się niewłaściwymi zachowaniami w aspekcie ilości, sposobu, częstości jedzenia posiłków, a także jakości potraw oraz towarzyszących emocji. Na występowanie zaburzeń odżywiania się ma wpływ szereg czynników. Nigdy nie należy kończyć leczenia na etapie pomocy w objawach somatycznych.

Wnioski. Niewątpliwie bardzo ważna jest rola pielęgniarki w opiece nad osobą z zaburzeniami odżywiania i profilaktyce tych stanów.

Słowa kluczowe: zaburzenia odżywiania, młodzież, opieka pielęgniarska 


\section{Summary}

Introduction. Eating disorders are a very important health problem of the 21st century, both in Poland and in the world. It mainly affects girls in adolescence and young women, but more and more boys suffer from eating disorders. This group, in terms of creating their own nutritional attitudes, is characterized by high susceptibility to socio-cultural and family influence.

Aim. The aim of the study is to analyze selected eating disorders in the light of the literature on the subject.

Material and methods. The study analyzes the literature on eating disorders. Overview. Eating disorders are defined as a way of eating harmful to an individual that manifests itself in inappropriate behavior in terms of the quantity, manner, frequency of eating meals, as well as the quality of dishes and accompanying emotions. A number of factors influence the occurrence of eating disorders. Treatment should never be discontinued while at the somatic symptom relief stage.

Conclusions. Undoubtedly, the role of the nurse is very important in the care and prevention of a person suffering from eating disorders.

Keywords: eating disorders, adolescents, nursing care

\section{Wstęp}

Zaburzenia odżywiania definiowane są jako szkodliwy dla jednostki sposób odżywiania przejawiający się niewłaściwymi zachowaniami w aspekcie ilości, sposobu, częstości jedzenia posiłków, a także jakości potraw oraz towarzyszących emocji. Zachowania te mają negatywny wpływ na funkcjonowanie organizmu, relacje społeczne, sferę uczuć, a także wielowymiarowy rozwój człowieka [1].

\section{Przegląd}

Według klasyfikacji ICD-10 najczęściej występujące jednostki należące do grupy zaburzeń odżywiania to: jadłowstręt psychiczny, żarłoczność psychiczna oraz nieokreślone zaburzenia odżywiania, np. ortoreksja [2]. 
Zgodnie z nową klasyfikacją chorób i zaburzeń psychicznych DSM-5 wyodrębniono 7 zaburzeń odżywiania:

- pica;

- zaburzenie przeżuwania;

- zaburzenie polegające na ograniczanie przyjmowania pokarmów;

- jadłowstręt psychiczny (anorexia nervosa - AN) - postać ograniczająca (restrykcyjna) oraz postać z napadami objadania się lub przeczyszczaniem;

- żarłoczność psychiczna (bulimia nervosa - BN);

- zaburzenie przebiegające z napadami objadania się (binge eating disorder - BED);

- inne nieokreślone zaburzenia odżywiania się [2].

Wszystkie zaburzenia odżywiania można podzielić na dwie grupy: specyficzne i niespecyficzne. Do pierwszej należą: jadłowstręt psychiczny, żarłoczność psychiczna oraz ich formy atypowe. Drugą grupę stanowią zaburzenia nietypowe, które nie spełniają warunków określonych zaburzeń odżywiania. Należą do nich: ortoreksja, bigoreksja nervosa, zespół jedzenia nocnego oraz zespół gwałtownego objadania się [3].

\section{Epidemiologia}

Warto zauważyć, że występowanie stanowi najważniejszy czynnik różnicujący płciowo zaburzenia odżywiania. Najwyższe wskaźniki zachorowalności na anoreksję notuje się wśród populacji dziewcząt w wieku 15-19 lat. Obejmują one nawet 40\% wszystkich nowo zdiagnozowanych przypadków. Objawy natomiast pojawiają się najczęściej między 14 a 18 r.ż. Należy zwrócić uwagę na to, iż zwiększa się także liczba dziewcząt $w$ wieku <12 r.ż. zgłaszających się na terapię z powodu zaburzeń odżywiania. Częstość występowania jadłowstrętu psychicznego wśród kobiet szacuje się na 0,51-3,7\%. Mężczyźni bardzo rzadko są w grupie pacjentów cierpiących na anoreksję. Występowanie tego zaburzenia u dojrzewających chłopców oraz dorosłych mężczyzn szacuje się na ok. 0,1\%. Wskazuje się jednak na zbyt małą liczbę prowadzonych 
badań epidemiologicznych wśród osób płci męskiej ze zdiagnozowaną anoreksją oraz fakt, iż jednym z kryteriów niezbędnym do rozpoznania jadłowstrętu psychicznego są zaburzenia miesiączkowania [2].

W przypadku bulimii również widoczna jest znaczna przewaga występowania tego zaburzenia wśród populacji kobiet. Według badań epidemiologicznych 0,34-1,5\% dziewcząt oraz młodych kobiet cierpi na bulimię, zaś niepełnoobjawowe zespoły bulimii dotyczą aż 8\% osób płci żeńskiej. W przypadku mężczyzn zapadalność na żarłoczność psychiczną jest wyższa niż w anoreksji i wynosi 0,1-0,7\% [2].

Nieco inaczej kształtuje się rozpowszechnienie zaburzeń odżywiania o charakterze gwałtownego objadania się. Szacuje się, że 20-40\% osób z zaburzeniami przebiegającymi z napadami objadania się (BED) to mężczyźni. Występowanie BED w ogólnej populacji ludzi wynosi 1-5\%, wśród kobiet 3,5\%, zaś wśród mężczyzn do 2\% [4].

Warto zwrócić uwagę również na fakt, iż zaburzenia odżywiania najczęściej występują w rozwiniętych krajach zachodnich (Francja, Holandia, Wielka Brytania). Kultura zachodnia może być głównym czynnikiem predysponującym w szczególności do wystąpienia zaburzeń pod postacią ortoreksji [5].

\section{Przyczyny}

Rozważania nad przyczynami zachorowań na zaburzenia odżywiania mają bardzo długą historię, ze względu na wieloczynnikowość, heterogenność oraz złożoność tych zaburzeń. Można przez to rozumieć, iż zaburzenia odżywiania powstają $\mathrm{w}$ wyniku połącznia wielu czynników - indywidualnych, biologicznych, społeczno-kulturowych [2].

Rola rodziców w kształtowaniu poczucia wartości i samooceny dziecka jest niezaprzeczalna. Kiedy rodzice są nadopiekuńczy lub przesadnie wymagający, dziecko bardzo szybko zaczyna tracić wiarę we własne możliwości. Wywarta na dziecku presja na spełnianie oczekiwań rodziców może doprowadzić do zaburzenia wyrażania własnych emocji i potrzeb oraz utraty wiary we własne siły [3]. 
Czynniki kulturowe stanowią bardzo istotne podłoże etologiczne zaburzeń odżywiania. Są to:

- presja wywierana przez media dotycząca odchudzania się i stosowania diety;

- silna koncentracja na własnym wyglądzie oraz niezadowolenie z niego;

- idealizowanie szczupłej sylwetki;

- stygmatyzowanie otyłości [2,3].

Media mają ogromny wpływ na odżywianie się człowieka. W środkach masowego przekazu promowany jest kult szczupłego, idealnego ciała. Niemożliwy do osiągnięcia ideał zwiększa niezadowolenie i krytycyzm wobec własnego obrazu ciała [2].

Czynniki wyzwalające, czyli bezpośrednio wywołujące objawy choroby to:

- depresja i wahania nastroju;

- podejmowanie restrykcyjnej diety na skutek poczucia bycia „za grubym";

- reakcja na nowe doświadczenia np. podjęcie nauki w nowej szkole;

- przykre doświadczenia życiowe [2].

Czynniki podtrzymujące to grupa warunków, które tworzą się w czasie trwania choroby, oraz które wpływają na dalsze jej istnienie.

\section{Przebieg zaburzeń odżywiania}

Każde z podstawowych zaburzeń odżywiania się obejmuje nieprawidłowe zachowania w obszarze nawyków żywieniowym, które doprowadzają do zakłóceń masy ciała, a nawet wyniszczenia [6,7].

Jadłowstręt psychiczny jest schorzeniem o podłożu psychicznym, które objawia się świadomym, rygorystycznym ograniczaniem przyjmowanych pokarmów, a także silnym koncentrowaniem się na wyglądzie i masie ciała, czemu towarzyszy paniczny strach przed przybraniem na wadze [7]. Jednocześnie pojawia się zaburzone postrzeganie 
obrazu własnej sylwetki, co prowadzi do poważnych zaburzeń w funkcjonowaniu organizmu [8].

Sygnały świadczące o anoreksji, na które należy zwrócić uwagę zarówno w środowisku szkolnym, jak i domowym to:

- BMI mniejsze niż 18,5;

- silny lęk przez zwiększeniem masy ciała lub otyłością, nawet przy niedowadze;

- coraz bardziej restrykcyjne jakościowo oraz ilościowo ograniczenia dietetyczne, będące świadomym dążeniem do niedowagi;

- poczucie sukcesu przy zmniejszaniu masy ciała;

- znaczny spadek masy ciała, nawet do $10 \mathrm{~kg}$ na miesiąc;

- zanik miesiączki;

- nieprawidłowe obniżanie masy ciała oraz wymiarów, np. poprzez stosowanie środków przeczyszczających, moczopędnych, tłumiących łaknienie;

- lekceważenie konsekwencji gwałtownego spadku wagi;

- spożywanie pożywiania w samotności;

- uprawianie intensywnych oraz bardzo wyczerpujących ćwiczeń fizycznych;

- kłamanie o ilości zjedzonego pożywienia, wymyślanie pretekstów na omijanie posiłków, wyrzucanie lub ukrywanie swoich porcji jedzenie (karmienie psa, oddawanie śniadania kolegom w szkole, wypluwanie jedzenia do toalety lub chusteczki, przeżuwanie, rozgrzebywanie porcji na talerzu, wymigiwanie się od jedzenia brakiem apetytu);

- początkowo bardzo chętne pokazywanie efektów diety poprzez noszenie obcisłych ubrań, rozmowy o odchudzaniu, jednakże później stopniowe ukrywanie swojej chudej sylwetki z obawy przed wizytą u lekarza;

- przejście na wegetarianizm pod pretekstem zdrowego odżywiania lub ideologii;

- widoczne objawy fizyczne, będące konsekwencją wychudzenia tj.: uczucie zimna, szara sucha skóra, łamliwe paznokcie, zabu- 
rzenia rytmu serca, omdlenia, bóle brzucha, osłabienie zębów i dziąseł, zawroty głowy, brak sił, charakterystyczny meszek na skórze będący wynikiem hipotermii;

- nadmierna szczupłość, aż do objawów skrajnego wychudzenia, obrzęk brzucha oraz twarzy z powodu niedoboru białka;

- objawy w sferze psychicznej to: w początkowym etapie choroby poczucie dumy, wręcz euforia z powodu spadku masy ciała, jednak wraz z postępem choroby i postępującym wyniszczeniem charakterystyczne rozdrażnienie, apatia przechodząca następnie $w$ depresję oraz myśli samobójcze. Ponad połowa zgonów w anoreksji następuję w wyniku samobójstwa [2].

Istotą bulimii są napady objadania się, wynikające z napięcia emocjonalnego i przegłodzenia. Charakterystyczne dla tego schorzenia są zachowania kompensacyjne występujące po napadach żarłoczności, tj.: prowokowanie wymiotów, stosowanie środków przeczyszczających i moczopędnych, głodówki czy intensywne ćwiczenia [2].

Objawy mogące świadczyć o bulimii, na które należy zwrócić uwagę to:

- jedzenie dużych porcji pokarmu w bardzo krótkim czasie. Osoby chorujące na bulimię zjadają np. w przeciągu 2 godzin takie ilości jedzenia, które dla zdrowego człowieka są zdecydowanie za duże do spożycia w tym samym czasie i okolicznościach.

- poczucie braku kontroli nad jedzeniem w trakcie epizodu objadania się. Chory w tym czasie jest przekonany, iż nie może zaprzestać jeść.

- zachowania, służące zapobieżeniu przybierania na wadze po atakach objadania się: prowokowanie wymiotów, stosowanie środków przeczyszczających i moczopędnych, intensywne ćwiczenia fizyczne.

- poziom samooceny wyznaczony jest przez wpływ wagi i kształtu ciała [8].

Nie należy jednak mylić bulimii z zespołem kompulsywnego objadania się (BED). Mimo, iż objawy są bardzo podobne, w przypadku BED 
po epizodach gwałtownego objadania się nie występują niewłaściwe zachowania kompensacyjne takie jak np. prowokowanie wymiotów czy nadużywanie leków przeczyszczających [6].

Zaburzenia odżywiania występują także w postaci niepełnoobjawowej. Nie spełniają w DSM-5 i ICD-10 kryteriów diagnostycznych i są ujęte w grupie zaburzeń łaknienia nieokreślonych inaczej. Do tego typu zaburzeń zalicza się m.in. ortoreksję, czyli obsesję na punkcie zdrowej żywności i zdrowego trybu życia. Pojęcie „ortoreksja” zostało wprowadzone po raz pierwszy przez amerykańskiego lekarza S. Bratmana w 1997 roku, który osobiście zmagał się z tym schorzeniem [3,9].

Początek ortoreksji najczęściej zaczyna się od stopniowego wprowadzania zmian żywieniowych w celu poprawy swojej kondycji oraz zmniejszenia ryzyka chorób. Chorzy motywują swoje decyzje o wycofaniu z diety produktów niezdrowych obawą o stan zdrowia w przebiegu np. alergii oraz nietolerancji niektórych składników pokarmowych. Te motywy uznawane są za zmiany pozytywne. Jednakże granica między zdrowym odżywianiem, a obsesją na tym punkcie jest praktycznie niewidoczna [5,9]. Ortorektyk eliminuje ze swojego jadłospisu produkty, które według niego są niezdrowe, pozostawiając tylko kilka produktów uznawanych przez niego za odpowiednie. W skrajnych przypadkach osoba chora jest przekonana, że jedynym zdrowym produktem jest woda, na dodatek specjalnie wyselekcjonowana. Produkty żywnościowe zwykle kupowane są w sklepach ekologicznych, a ich etykiety dokładnie analizowane pod kątem obecności sztucznych barwników i konserwantów. Chory unika zakupów w dużych sklepach [8]. Osoby $\mathrm{z}$ ortoreksją bardzo dużą uwagę przykładają do przygotowania posiłków, ważna jest bowiem dla nich wartość kaloryczna spożywanych pokarmów i dokładne ich zaplanowanie, a złamanie przyjętych zasad musi być przez nich ukarane. Po przyrządzeniu posiłku, każdy kęs pożywienia kilkukrotnie przeżuwają. Myślenie i rozmowy o jedzeniu stają się istotą każdego dnia, do tego stopnia, iż chory unika spotkań ze znajomymi, które wynikają z rygorystycznej diety oraz konieczności przy- 
gotowywania przez niego specjalnych posiłków. Zdarza się zatem, że na spotkania z bliskimi przynosi własne potrawy [9].

W przebiegu ortoreksji pojawia się również wiele objawów somatycznych, będących następstwem niewystarczającej podaży składników odżywczych w wyniku nieprawidłowego odżywiania. Na początku chory skarży się na bóle i zawroty głowy, osłabienie, problemy z koncentracją, nudności oraz bóle brzucha. Ze względu na niedobory głównych składników odżywczych, mikroelementów i witamin może wystąpić spadek odporności, niedokrwistość, czy depresja. Wzrasta również ryzyko wystąpienia odmy opłucnowej, rozedmy podskórnej, hiponatremii czy niedoboru składników morfotycznych krwi $[7,10]$.

\section{Diagnostyka i leczenie wybranych zaburzeń łaknienia}

Zaburzenia odżywiania mają podłoże somatyczne, jednak klasyfikowane są jako zaburzenia natury psychicznej. Świadczą o tym charakterystyczne symptomy oraz etiologia tych zaburzeń. Według Międzynarodowej Klasyfikacji Zaburzeń Psychicznych ICD-10 zaburzenia odżywiania się należą do zespołów behawioralnych przebiegających z zaburzeniami fizjologicznymi oraz czynnikami fizycznymi [11].

W przypadku dzieci i młodzieży poniżej 15 r.ż. ubytek masy ciała określany jest na podstawie centyli wskaźnika masy ciała lub centyli wzrostu i masy ciała właściwych dla wieku. Różnica powyżej dwóch kanałów centylowych między ciężarem ciała odpowiednim dla wieku, a wzrostem również stosownym do wieku świadczy o obecnym zaburzeniu. W przypadku osób powyżej 15 r.ż. stopień nasilenia zaburzenia określa się na podstawie wskaźnika BMI $[2,12]$.

Zakres wartości BMI i ocena jego stopnia ciężkości

- Łagodny $\quad$ BMI $\geq 17 \mathrm{~kg} / \mathrm{m}^{2}$

- Umiarkowany BMI 16-16,99 kg/m²

- Ciężki BMI $15-15,99 \mathrm{~kg} / \mathrm{m}^{2}$

- Bardzo ciężki BMI $<15 \mathrm{~kg} / \mathrm{m}^{2}$ [12].

Rozpoznanie ortoreksji jest bardzo trudne, z uwagi na pozytywną tendencję prozdrowotną na początku rozwoju choroby. Osoba 
prezentująca właściwą postawę wobec żywienia, będzie ograniczała pożywanie słodyczy, słodkich i gazowanych napojów, używek, smażonych potraw, a wzbogacała swoją dietę w niezbędne i cenne składniki np. wielonienasycone kwasy tłuszczowe. Osoba zdrowa jest świadoma potrzeb swojego organizmu. Natomiast osoba zagrożona ortoreksją będzie eliminować ze swojego jadłospisu kolejne rodzaje potraw, zamiast go wzbogacać [7].

Pomimo rosnącego zainteresowania zjawiskiem ortoreksji na świcie, w literaturze nie ma powszechnie akceptowanych założeń diagnostycznych tego zaburzenia. Pierwsze kryteria rozpoznania ortoreksji zaproponowali S. Bratman oraz D. Knight, którzy to opierając się na własnych doświadczeniach zaproponowali badanie w formie wywiadu (The Orthorexia Self-Test). Test Bratmana posłużył jako baza do opracowania przez L. M. Doniniego wraz z zespołem Uniwersytetu La Sapienza bardziej złożonych kryteriów. Według nich zdiagnozowanie ortoreksji powinno opierać się na następujących kryteriach:

- stwierdzenie cech osobowości obsesyjno-kompulsywnej;

- występowanie przesadnego przywiązania do zdrowego odżywiania;

- stały, nieprzejściowy charakter zaburzenia;

- wykazanie, że zachowania związane ze spożywaniem posiłków mają negatywny wpływ na jakość życia [5, 9].

$\mathrm{Na}$ podstawie wyżej wymienionych kryteriów opracowano narzędzie do diagnozowania ortoreksji - Kwestionariusz ORT0-15, który uwzględnia również elementy zaproponowane przez Bratmana i Knighta. Test ten składa się z 15 pytań opisujących nasilenie zachowań ortorektycznych. Podstawą badań w opracowanym kwestionariuszu są postawy żywieniowe wobec kupowania, przygotowywania oraz spożywania posiłków uznawanych za zdrowe [5,9].

Diagnostyka ortoreksji powinna być nie tylko poprzedzona właściwym odróżnieniem od innych zaburzeń łaknienia, w szczególności anoreksji, ale również zawierać dogłębną analizę aspektów rozwojowych 
i wychowawczych, z psychologiczną oceną wymiaru poznawczego oraz emocjonalnego $[5,9]$.

Leczenie zaburzeń odżywiania jest długofalowe i obejmuje somatyczne, psychiatryczne i psychologiczne aspekty choroby. Amerykańskie Towarzystwo Psychiatryczne sformułowało w 2006r. szereg wskazań dotyczących leczenia psychiatrycznego zaburzeń łaknienia:

Postępowanie psychiatryczne stanowi bazę leczenia osób z zaburzeniami odżywiania i powinno być ono przeprowadzane u wszystkich chorych w połączeniu z innymi indywidualnymi oddziaływaniami terapeutycznymi $[2,11]$.

Cele leczenia:

- zbudowanie i utrzymanie związku terapeutycznego z pacjentem;

- dopasowanie leczenia poprzez współpracę z innymi specjalistami (psychiatra, internista, ginekolog, endokrynolog, gastrolog, stomatolog, psychoterapeuta, dietetyk, rehabilitant ruchowy czy terapeuta manualny);

- ocena i monitorowanie zachowań pacjenta oraz objawów zaburzeń odżywiania;

- ocena i monitorowanie ogólnego stanu chorego;

- kontrolowanie stanu psychicznego pacjenta oraz jego bezpieczeństwa;

- ocena sytuacji rodzinnej i ewentualne zaproponowanie terapii rodzinnej $[2,11,12]$.

Pierwszorzędnym elementem leczenia w zaburzeniach odżywiania się jest wyeliminowanie bezpośrednio zagrażających życiu pacjenta objawów somatycznych. Szczególnie istotnym zagadnieniem dla rodziców chorego dziecka jest wybór miejsca leczenia. Główne wskazania do hospitalizacji osób z zaburzeniami odżywiania to:

- BMI u pacjentów dorosłych poniżej 16 lub spadek masy ciała poniżej 25\% masy prawidłowej;

- gwałtowny spadek ilości spożywanych pokarmów;

- zagrażające powikłania somatyczne takie jak: zaburzenia rytmu serca, bradykardia, zaburzenia elektrolitowe; 
- wystąpienie infekcji przy niskiej masie ciała;

- nasilone, gwałtowne i niekontrolowane napady bulimii;

- współistniejące inne zaburzenia psychiczne takie jak: depresja, nasilone stany lękowe, zaburzenia obsesyjno-kompulsywne;

- ciężkie uzależnienia od substancji psychoaktywnych lub alkoholu $[2,11]$.

Bez wątpienia w przypadku wystąpienia nasilonych objawów somatycznych takich jak: wyniszczenie, zaburzenia w układzie sercowo-naczyniowym, zaburzenia elektrolitowe odpowiedniejsze będzie hospitalizowanie pacjenta w oddziale interny, OIOM lub pediatrii w przypadku dzieci. Po uzyskaniu poprawy wskazana jest kontynuacja leczenia w oddziale psychiatrii $[2,11]$.

Warto podkreślić, iż nigdy nie należy kończyć leczenia na etapie pomocy w objawach somatycznych. Wielu pacjentów powraca do choroby po przybraniu na wadze w warunkach szpitalnych. Potwierdza to fakt, iż przyczyny zaburzeń odżywiania kryją się w poważnych nieprawidłowościach emocjonalnych. Z uwagi na to bardzo istotne jest wprowadzenie leczenia psychoterapeutycznego zaraz po zakończeniu hospitalizacji [11].

Według badań przeprowadzonych przez Amerykańskie Stowarzyszenie Psychiatrów szczególną rolę w leczeniu zaburzeń odżywiania odgrywa terapia rodzinna oraz psychoterapia indywidualna, które stanowią podstawę $\mathrm{w}$ procesie terapeutycznym dzieci i młodzieży $[2,7$, 11]. Wykorzystuje się również inne rodzaje terapii, które dobierane są indywidualnie:

- terapia interpersonalna;

- terapia behawioralno-poznawcza;

- terapia oparta na samopomocy;

- psychoedukacja;

- terapia zaburzeń obrazu ciała;

- terapia analityczno-poznawcza;

- terapia ukierunkowanych wyobrażeń;

- terapia podtrzymująca;

- terapia grupowa $[2,7,11,12]$. 


\section{Rola pielęgniarki w opiece nad osobą z zaburzeniami łaknienia}

Zapotrzebowanie na opiekę medyczną u osób cierpiących na zaburzenia łaknienia jest bardzo duże. Szacuje się, iż u co najmniej połowy pacjentów z zaburzeniami odżywiania choroba została zdiagnozowana przez zespół terapeutyczny podstawowej opieki zdrowotnej. Mimo, iż lekarze rodzinni odgrywają ogromną rolę $w$ rozpoznawaniu oraz leczeniu tych zaburzeń, często ze względu na niewystarczające wyszkolenie w tym zakresie, stwierdzają wystąpienie zaburzeń odżywiania u pacjenta dopiero wtedy, kiedy konsekwencje choroby są już zaawansowane. W takiej sytuacji najczęściej pacjenci kierowani są do szpitala. Większość osób z zaburzeniami odżywiania się, którzy są hospitalizowani to osoby ze zdiagnozowanym tzw. zaburzeniem odżywiania nieokreślonym w inny sposób. Zaliczyć można do niego ortoreksję [13].

Współczesna psychiatria, realizując ideę kompleksowego leczenia i opierając się na holistycznej koncepcji człowieka, stwarza nowe obszary zadań dla całego zespołu terapeutycznego, dlatego też niezbędny jest udział pielęgniarki jako: członka społeczności terapeutycznej, partnera $\mathrm{w}$ relacji z chorym oraz jego rodziną, profesjonalistki w dziedzinie profilaktyki zaburzeń psychicznych i promocji zdrowia psychicznego w różnych środowiskach. Zadania pielęgniarki opiekującej się osobą z zaburzeniami łaknienia sprowadzają się głównie do poznania istoty choroby, eliminowania lęku przed przyrostem masy ciała, zmotywowania do współpracy w procesie terapeutycznym, uzyskania realistycznej oceny własnej sylwetki i wagi, a także zmiany zachowań. Pielęgniarka dzięki swojej bezpośredniej oraz uczestniczącej obserwacji codziennych zajęć pacjenta zgłasza jego postępy i trudności w leczeniu, a także razem $\mathrm{z}$ całym zespołem terapeutycznym podejmuje decyzje o kolejnych działaniach terapeutycznych i pielęgnacyjnych, włączając się tym samym w spójną strategię zespołu wobec chorego [13, 14].

Podstawowym zadaniem hospitalizacji pacjenta z zaburzeniami odżywiania jest poprawa jego stanu somatycznego i doprowadzenie do możliwości kontynuacji leczenia ambulatoryjnego. Zadaniem pielęgniarki przyjmującej pacjenta do oddziału jest: 
- nawiązanie komunikacji z pacjentem i jego rodziną;

- stworzenie atmosfery wzajemnego zaufania;

- zapoznanie z regulaminem oddziału oraz programem leczenia, tj.: czas trwania posiłków, przepustki, ważenie, odwiedziny, udział w zajęciach terapeutycznych;

- pomiar parametrów życiowych: RR, tętno, wzrost i masa ciała, temperatura ciała;

- przegląd rzeczy osobistych w kierunku posiadania np. leków przeczyszczających, odwadniających;

- sformułowanie hierarchii problemów pielęgnacyjnych;

- we współpracy z dietetykiem ustalenie indywidualnej diety odpowiedniej dla pacjenta;

- systematyczne prowadzenie dokumentacji w tym kart obserwacyjnych kontroli parametrów życiowych [14].

Priorytetowym zadaniem pielęgniarki $\mathrm{w}$ opiece nad pacjentem z zaburzeniami odżywiania w szpitalu jest zapobieganie zagrożeniu życia, które jest następstwem powikłań nieprawidłowego odżywiania się. W takiej sytuacji pielęgniarka:

- podaje zlecone przez lekarza płyny dożylne w celu zrównoważenia gospodarki wodno-elektrolitowej;

- prowadzi bilans płynów;

- obserwuje oraz dokumentuje ilość spożywanych posiłków;

- w przypadku długotrwałej odmowy przyjmowania pokarmów zakłada zgłębnik żołądkowy na zlecenie lekarza, przez który podaje mieszanki odżywcze;

- dokonuje holistycznej obserwacji pacjenta: stanu somatycznego, psychicznego oraz funkcjonowania społecznego [14].

Pielęgniarka w oparciu o wiedzę z zakresu psychiatrii, socjologii, psychologii i pedagogiki, wraz z ukierunkowaną obserwacją zachowań pacjenta, określa jego problemy, jednocześnie obierając cele, do których będzie dążyć razem z chorym, jego rodziną oraz całym zespołem terapeutycznym [14]. 
Szczególną rolę odgrywa zespół pielęgniarski w leczeniu żywieniowym pacjenta. Pielęgniarka wprowadza ustaloną wcześniej dietę, obserwuje i kontroluje zachowania chorego w trakcie oraz bezpośrednio po spożyciu pokarmów tzn.: zwraca uwagę na ilość przyjmowanych produktów, czas trwania posiłku, obserwuje występowanie zachowań takich jak: chowanie i wyrzucanie jedzenia, podrzucanie innym pacjentom, zrzucanie ze stołu, prowokowanie wymiotów, regularne ważenie, wykonywanie ćwiczeń fizycznych [14].

Pielęgniarka uczestniczy również $\mathrm{w}$ planowaniu postępowania terapeutycznego, zmierzającego do zmiany nieprawidłowego obrazu ciała pacjenta oraz poprawy jego funkcjonowania w życiu społecznym. Wykorzystując psychoterapię, psychoedukację oraz rozmowy z chorym dąży do zmiany jego postaw względem odżywiania. Przekazuje także wiedzę na temat istoty zaburzenia, wskazując na przyczyny i powikłania, wyjaśnia znaczenie spożywania poszczególnych składników odżywczych i mikroelementów, a poprzez zajęcia relaksacyjne dąży do zminimalizowania lęku [14].

W kompleksowym planie opieki pielęgniarskiej nad osobą z zaburzeniami odżywiania szczególną uwagę należy zwrócić na udział rodziców pacjenta, którzy ze względu na swoje poczucie niekompetencji oraz bezradności, narażeni są na stres związany z chorobą dziecka [15]. Ważne jest, aby pielęgniarka rozpoznała sytuację rodzinną, problemy związane ze zmianą zachowania pacjenta, reakcje emocjonalne i dokonała oceny możliwości wsparcia pomiędzy rodzicami a dzieckiem. W trakcie rozmów terapeutycznych, pielęgniarka poprzez swoje partnerstwo z rodziną pacjenta udziela rzetelnych informacji na temat choroby dziecka, próbując tym samym wypracować konstrukcyjne sposoby radzenia sobie $\mathrm{z}$ nią $\mathrm{w}$ codziennym funkcjonowaniu, jednocześnie umożliwiając rodzicom chorego wyrażanie swoich obaw i uczuć [14].

\section{Profilaktyka zaburzeń odżywiania}

Działania profilaktyczne zaburzeń odżywiania powinny być oparte przede wszystkim o kształtowanie prawidłowego wizerunku własnego 
ciała i mogą być realizowane w wymiarze indywidualnym oraz instytucjonalnym. W wymiarze indywidualnym największą rolę odgrywa oddziaływanie rodziców, gdyż to oni przede wszystkim wpływają na postrzeganie ciała swoich dzieci przez kształtowanie zachowań i opinii. Działania, które powinni podejmować rodzice w celu promowania pozytywnego wizerunku ciała swojego dziecka to:

- zapewnienie stymulacji sensorycznej dziecka od lat najmłodszych, co daje mu poczucie bezpieczeństwa;

- zachęcanie dziecka do eksperymentowania z różnymi formami zajęć fizycznych, co przyczynia się do rozwoju poczucia własnej skuteczności;

- niedopuszczenie do niewłaściwych komentarzy na temat wyglądu dziecka, uczenie go, jak reagować na nieprzychylne uwagi oraz wspólne minimalizowanie negatywnych doświadczeń;

- uczenie dziecka zwracania uwagi na sygnały takie jak: głód, nasycenie, zmęczenie;

- uczenie dziecka krytycyzmu wobec informacji rozpowszechnianych przez media, uświadamianie, iż przekazy zawarte w kolorowej prasie, reklamach, teledyskach rzadko odpowiadają rzeczywistości;

- rozmawianie z dzieckiem na temat zmian, jakie zachodzą w ciele podczas okresu dojrzewania;

- zmotywowanie dziecka do samodzielnego określenia obrazu swojego ciała, tak, aby nie kierowało się opinią i uwagami innych [16].

Oprócz inicjatywy rodziców, działania skierowane na kształtowanie pozytywnego wizerunku ciała oraz zapobieganie jego zniekształceniom powinny być inicjowane w wymiarze instytucjonalnym. Najważniejszą instytucją podejmująca takie działania jest szkoła, ze względu na jej systematyczny i długotrwały wpływ na dzieci i młodzież.

Profilaktyka I stopnia postępowanie adresowane do osób, u których nie występują zachowania dezadaptacyjne - zapobieganie poja- 
wieniu się zachowań szkodzących zdrowiu poprzez wczesne diagnozowanie czynników ryzyka oraz przeciwdziałanie im

Profilaktyka II stopnia czynności skierowane do osób, u których występują pojedyncze zachowania dezadaptacyjne, np. stosowanie restrykcyjnej diety - zapobieganie postępowania zaburzenia w momencie pojawienia się jego pierwszych objawów

Profilaktyka III stopnia działania adresowane do osób, u których wystąpiły w przeszłości zaburzenia odżywiania; czynności te mają na celu przeciwdziałanie nasileniu zaburzeń lub ich ponownemu wystąpieniu, a także łagodzenie ich szkodliwych skutków [17].

\section{Wnioski}

Wszystkie zaburzenia łaknienia głównie występują u dziewcząt w wieku dojrzewania. Grupa ta, biorąc pod uwagę kreowanie własnych postaw żywieniowych, charakteryzuje się dużą podatnością za wpływ społeczno-kulturowy.

Z uwagi na to, iż przyczyny zaburzeń odżywiania kryją się w nieprawidłowościach emocjonalnych, bardzo istotne jest wprowadzenie leczenia psychoterapeutycznego po zakończeniu hospitalizacji. Szczególną rolę ogrywa terapia rodzinna oraz psychoterapia indywidualna.

Problemy rodzinne oraz kryzysy przyczyniają się do uzewnętrznienia zachowań anorektycznych, bulimicznych lub ortorektycznych.

Niewątpliwie bardzo ważna jest rola pielęgniarki w opiece nad osobą z zaburzeniami łaknienia, której zadania sprowadzają się przede wszystkim do poznania istoty choroby, zmotywowania do współpracy w procesie terapeutycznym, eliminowania lęku oraz zmiany niewłaściwych zachowań.

\section{Bibliografia / Bibliography:}

1. Tołubińska T., Myszkowska-Ryciak J., Harton A., Gajewska D. Ocena sposobu żywienia i stanu odżywienia oraz ryzyka wystąpienia zaburzeń odżywiania u młodzieży licealnej w wieku 16-20 lat. Bromat. Chem. Toksykol 2012;45(3):845-851. 
2. Gmitrowicz A., Janas-Kozik M. (red.) Zaburzenia psychiczne dzieci i młodzieży. Warszawa: Medical Tribune Polska; 2018:245-259.

3. Grasewicz J. B. Wpływ zaburzonego wizerunku ciała na powstawanie zaburzeń odżywiania się. Pielęgniarstwo i Zdrowie Publiczne 2016;6(4):315-322.

4. Nowogrodzka A., Piasecki B. Zaburzenia odżywiania - różnice międzypłciowe. Nowiny Lekarskie 2012;81(4):381-385.

5. Krawiec K., Żelazko-Szczurek J., Giermaziak W., Królak A. Ortoreksja - istotnym problemem zdrowia publicznego? Zdrowie Publiczne 2019;75(7):351-356.

6. Andruszko R. DSM-5 bez tajemnic. Praktyczny przewodnik dla klinicystów. Kraków: Wydawnictwo Uniwersytetu Jagiellońskiego; 2016:306323.

7. Rzońca E., Bień A., Iwanowicz-Palus G. Zaburzenia odżywiania - problem wciąż aktualny. Journal of Education, Health and Sport 2016;6(12):267273.

8. Kędra E. Zaburzenia odżywiania - znak naszych czasów. Pielęgniarstwo Zdrowia Publicznego 2011;1(2):169-175.

9. Krzywdzińska A., Hozyasz K. K. Ortoreksja - patologiczna kontrola nad odżywianiem. Zagrożenie dla dzieci i młodzieży. Pediatria Polska 2014;89:119-124.

10. Dittfeld A., Koszowska A., Fizia K., Ziora K. Ortoreksja - nowe zaburzenie odżywiania. Annales Academiae Medicae Silesiensis 2013;67(6):393399.

11. Żechowski C. Zaburzenia odżywiania się. Psychiatria 2007;15(4):494501.

12. Janas-Kozik M. Jadłowstręt psychiczny. Medycyna po Dyplomie 2016;5:6672.

13. Święcicki Ł. Rozpoznawanie i leczenie zaburzeń odżywiania się w podstawowej opiece zdrowotnej. Medycyna po Dyplomie 2011;20(7):43-49. 
14. Gawłowski K. Udział pielęgniarki w kompleksowym leczeniu jadłowstrętu psychicznego pacjenta hospitalizowanego. Puls Uczelni 2012;6(4):1721.

15. Pilecki M. W., Józefik B., Kościelniak M. Percepcja relacji w rodzinie pochodzenia pacjentek z zaburzeniami odżywiania się a percepcja relacji w rodzinach pochodzenia ich rodziców. Psychiatria Polska 2015;49(4):731746.

16. Jagielska G. One są wśród nas. Dziecko z zaburzeniami odżywiania w szkole i przedszkolu. Informacje dla pedagogów i opiekunów. Warszawa: Ośrodek Rozwoju Edukacji; 2010:21-22.

17. Wycisk J., Ziółkowska B. Młodzież przeciwko sobie. Zaburzenia odżywiania i samouszkodzenia - jak pomóc nastolatkom w szkole. Warszawa: Wyd. Difin; 2010:135. 